African Journal of Educational Studies in Mathematics and Sciences Vol. 15, No. 2., 2019

\title{
Perception of learning science: the case of females offering STEM majors in Ghana
}

\author{
D. K. ${ }^{1}$ Amponsah, \& M. S. ${ }^{2}$ Mohammed
}

\begin{abstract}
The study investigated the differences among female students pursuing selected STEM programmes in a Science and Technology university in Ghana, in their perception of learning science. Three hundred and twenty-eight (328) final year female students offering computer science and information and communication technology, engineering, pharmacy, and medicine formed the sample. The research design was descriptive cross-sectional survey, and a questionnaire was utilised for data collection. The reliability coefficient obtained using Cronbach alpha formula was 0.85 . The study discovered that female students in STEM majors were goaloriented and extraordinarily impressive with their academics however lacked the capacity to have fun as a result of loaded curriculum. Again, the study showed specific differences in selfperception among students of the four STEM majors, when analysed using ANOVA and Post hoc analyses. It was revealed that pregnancy is no longer a barrier to educate the girl child as a result of unique interventions put in place by the government of Ghana. It was recommended among others that the Ghana Education Service intensifies the STEM training Clinics in the rural areas of Ghana to enhance rural female students' involvement in STEM Majors at Tertiary level.
\end{abstract}

Keywords: $\quad$ females, perception, self-perception, STEM majors, science and technologybased university programmes (STU)

\section{Introduction}

Ghana government, to inspire learners to enthusiastically participate in science and technology activities introduced programmes like the "Science, Technology, Engineering, and Mathematics" (STEM) clinic and technical drawing for both boys and girls at the basic school level in every District of Ghana (Baryeh, Lamptey \& Obu, 1999 as cited in Amponsah, Mensah, \& Mensah, 2014). Correspondingly, the Ministry of Education revealed that resolute efforts are been executed to intensify female access to apprenticeship areas of technical education and training in order to increase female involvement in "Technical and Vocational Education and Training" (TVET) in Ghana, (Ghana MOE, 1994 as cited in Amponsah, \& Mensah, 2014). This is also to safeguard that women pursuing STEM roles face less stigma, although current figures reveal that government needs more conscientisation, incentivisation, and public education among others in order that the gap between male and female participation in science might be closed (Baryeh, et al., 1999 as cited in Amponsah, Mensah, \& Mensah, 2014; DuBow, 2013). Females face a lot of cultural biases, such as gender-specific norms and role expectations which influences the way they are taught and their choice of subjects at school. This has culminated in the underrepresentation of women in critical areas such as STEM majors, and subsequently in STEM occupations (Sainz, 2011). Existing literature suggests that the number of students, especially female (more than fifty percent of the population) graduates in STEM-related careers is inadequate to fill the ever-

\footnotetext{
${ }^{1}$ Amponsah, Kwaku Darko and ${ }^{2}$ Mohammed, Salifu Maigari are both in the Department of Teacher Education, P. O. Box LG 1181, University of Ghana, Legon, Accra, Ghana. Emails: kdamponsah@ug.edu.gh; smmohammed@ug.edu.gh

Open Access article distributed under the terms of the Creative Commons Attributions License [CC BY-NC-ND 4.0] http://creativecommons.org/licenses/by-nc-nd/4.0. DOI: https://dx.doi.org/10.4314/ajesms.v15i2.12
} 
Perception of learning science: the case of females offering STEM majors in Ghana

\section{K. Amponsah, \& M. S. Mohammed}

increasing job opportunities in STEM fields (DuBow, 2013; Langdon, McKittrick, Khan \& Doms, 2011). Even though there are a greater number of ladies than men research has revealed that ladies occupy about $25 \%$ of all STEM professions. Unfortunately, Women in STEM (2019) opined that the percentage has fundamentally persisted and marginally affected since 2015 from $25 \%$ to $26 \%$, which is very disturbing.

Similarly, the Department of Commerce in the United States has indicated that females who have earned STEM degrees continue to be underrepresented in STEM jobs although they keep on improving across the wider economy (Noonan, 2017). Again, statistics have shown that there is difference in the STEM gender chasm (Labour Department, 2017). Apart from biological, health and allied sciences where women account for over $50 \%$ of the employees, women make up less than $40 \%$ of the workforce in the other STEM related fields. For example, the labour department has indicated that America's engineering jobs are the least participated by women (16\%), followed by computer programming jobs $(21 \%)$, mathematics related jobs $(25 \%)$ and chemistry related jobs (38\%). Accordingly, Else-Quest, Mineo and Higgins (2013), on the shortage of females in STEM related fields have indicated that this phenomenon is a result of women's frame of mind to STEMrelated fields instead of ability. Additionally, further research by Women in STEM (2019) have shown that women perceive Engineering and Computer Science fields as an uninteresting area dominated by male enthusiasts who are highly studious intellectuals, with only $19 \%$ participation of females. This trend is very worrying as it might limit the representation of females in these fields as well as other STEM fields.

Kuiper (1991, as cited in Amponsah, Mensah, \& Mensah (2014) observed that even though women constitute a greater percentage of the population involved in economic activities in most African countries, yet most of the female workers is categorised having limited training or untrained (Baryeh, et al., 1999 as cited in Amponsah, Mensah, \& Mensah, 2014). Similarly, even though there has been a wide extension of educational and vocational opportunities opened to women, their low involvement in STEM fields is not very encouraging (Baryeh, et al., 1999, as cited in Amponsah, Mensah, \& Mensah, 2014). Some studies are of the view that the STEM gender gap is the cause of cultural training. For instance, at primary school, the potential of young girls to master mathematics and science are lessened as they are exposed to stereotypes that indicate that STEM careers are more appropriate for men. Consequently, the "American Association of University Women' (AAUW)" buttressed that "unconscious gender bias is a significant barrier to girls' progress in STEM" (AAUW, 2010). They pointed out that "early education plays a critical role in girls' development, setting the stage for their level of interest, confidence, and achievements, particularly in STEM" (AAUW, 2010, 2012, 2014, \& 2015).

\section{Theoretical Framework and Literature Review}

The theoretical framework is self-perception theory (SPT), which alludes that "self-perception theory describes the process in which people, lacking initial attitudes or emotional responses, develop them by observing their own behaviour and coming to conclusions as to what attitudes must have driven that behaviour" (David, 2017, p. 1). There is a standard understanding that attitudes control behaviours, yet the theory is contrary to common-sense expectation as the opposite seems to be suggested. Additionally, the theory advocates that individuals do not access their internal reasoning and mood states but rather influence attitudes (Robak, Ward \& Ostolaza, 2005). Individuals might explain their obvious behaviours reasonably just as they try to rationalize the behaviours of others. Thus, females might develop negative self-perception concerning STEM careers as a result of the stereotypic role expectations different cultures have imposed on them. Consequently, they tend to see themselves as being weak in mathematics and science right from primary school thereby accounting for their poor performance in these subjects. This suggests that 
a positive self-perception of females concerning their capabilities especially in mathematics and science will go a long way to enhance female participation in STEM subjects that will subsequently culminate to STEM careers.

Some studies were performed to test the relationship between SPT and mind wandering (MW) (Critcher \& Gilovich, 2010). According to Critcher and Gilovich, SPT postulates that individuals tend to interpret the meaning of their behaviour to control their attitudes and preferences. They also researched if individuals hinge on their innate behaviour (mind wandering) while deducing from their attitudes and inclinations. They suggested that monotony occurs if the mind digresses to constructive situations, to simultaneous instead of previous events, and many activities instead of just one and this might consequently lead to apparent disappointment with the task on hand. The researchers concluded that respondents will hinge on the substance of their MWs as an indicator to their opinions if an optional cause for their MW is not made known to them (Critcher \& Gilovich, 2010).

Similarly, a study was conducted on SPT and the investigators hypothesized that individuals occasionally deduce their characteristics or frames of mind by watching the freely picked activities of others with whom they have a feeling of merged identity, like they had watched themselves playing out the activities (Goldstein \& Cialdini, 2007). Members were made to feel a sense of combined personality with an entertainer through a standpoint-taking assignment or response showing intersecting designs of electrical impulse in the brain. Participants included characteristics that are critical to the entertainer's conduct into their self-perspective, thereby changing their behaviours (Goldstein \& Cialdini, 2007). This research focuses on the selfexpansion model, which suggests that close connections can prompt an incorporation of someone else in a person's self-feeling. Consequently, the perception people close to you have about you can influence your self-perception and consequently self-concept either positively or negatively depending on how it is incorporated into your system through your interactions.

Accordingly, a barricade to female's involvement in STEM education is a result of the traditional perception of the roles of women as being fundamentally domestic and hence need some basic or no education at all (Ogunjiyigbe, Ojofeitimi, and Akinlo, 2006 as cited in Amponsah, \& Mensah, 2014). This perception might be due to the conviction that girls are likely to be impregnated even though they are still schooling. They observed that a considerable number of women still hold on to their flawed notion that girls who get educated will at the end of the day bestow the benefits of schooling to the families of their husbands as soon as they get married. They affirmed that as young men are viewed as beneficiaries, responsible for the progression of the family tree, they ought to be given priority and more consideration as a result of the fact that Nigeria is a patriarchal society (Ogunjuyigbe et al., 2006 as cited in Amponsah, \& Mensah, 2014). Burchfield and Kadzamira (as cited by Ogunjuyigbe et al., 2006) were of the view that males and females' involvement in STEM education is inhibited by how males and females are groomed to act. Education is accepted to be progressively useful in grooming females for their occupations as mothers and life partners instead of for work. They concluded that there is a shortage of females in STEM careers because of inferior instructional outcomes and strong cultural barriers women must endure.

To efficaciously appeal to the best students and the brightest to the field of computer science, Gupta and Houtz (2000) conducted research to vividly comprehend the viewpoints and opinions of female and minority high school students towards computer use and technology careers. The reason being that there is a dearth of IT specialists in many countries in the world, including the United States (AAUW, 2015; Gupta \& Houtz, 2000). This situation is confirmed by Women in STEM (2019) who opined that although the percentage of females in mathematical and physical 


\section{K. Amponsah, \& M. S. Mohammed}

sciences has increased to $39 \%$, unfortunately, the percent of female engineering and technology graduates has persisted continuously low at 15\% from 2015 to 2018.

Camp (1997 as cited in Amponsah, \& Mensah, 2014) is of the view that there is a need for a consistent addition of IT specialists to the business community if the US is to continue to be competitive in the international market. However, in a study on "gender differences in college students' perceptions of technology-related jobs in computer science, female students placed less value on and had lower expectations for success in computer technology (CT) fields. They also had a lower personal interest in pursuing advanced studies in CT, and the value was the most predictive factor in explaining the interest in pursuing a CT degree" (Appianing, \& Van Eck, 2015, p.1). Despite the increasing requirements of the business community for excellent technical specialists, it is evidenced that the USA's educational institutions are incapable of meeting this demand (AAUW, 2015; Camp, 1997 as cited in Amponsah, \& Mensah, 2014). It is surprising that few students are opting for computer science and information technology programmes although salaries of technology professionals are rising steeply in the US, impressive additional bonuses and other perks.

It has been recognised that schools incline to reinforce and exacerbate sex stereotypes within the broader society (AAUW, 2015; Arnot \& Phipps; FAWE, as cited in Ogunjiyigbe, Ojofeitimi, \& Akinlo 2006). For instance, it has been found that the attitudes and perceptions exhibited by the larger society toward female involvement in science and technology are not different from those of the teachers. Strangely, both male and female teachers showed lower expectations for female scholarly performance concerning girls' academic achievement. Unfortunately, teachers perceived boys to be intelligent, industrious, inspired and supportive, whereas females were thought to be inactive, malleable, quiet, flexible and compliant (Basu; Davidson and Kanyuka; Kainja \& Mkandawire, as cited in Ogunjuyigbe et al., 2006). Such a negative perception of teachers toward females is demotivating, depressing and unfortunate and goes a long way to affect their performance in mathematics and science and subsequently their participation in STEM careers.

\section{Statement of the Problem}

The problem that prompted this research is that only a few female learners are pursuing STEMrelated programmes at public universities of Ghana regardless of the numerous government interventions such as the STEM clinic for girls and the 1990 policy on Vocational Education (Baryeh, Obu, Lamptey, 1999 as cited in Amponsah, Mensah, \& Mensah, 2014) to advance science and technology studies and to inspire more involvement of women. Despite these interventions, only a few female students are found offering STEM-related programmes at these public Universities of Ghana compared with female students' participation in the humanities (Amponsah, Mensah, \& Mensah, 2014). Even though the STEM field is dominated by males in Ghana, it still lags in its economic emancipation. It is therefore not surprising that Forje (1989) as cited in Amponsah, Mensah, \& Mensah, 2014) indicated that an honest cohesive socio-economic revolution can only be realised in African countries by completely integrating women into Science and Technology Education at the tertiary level. However, the traditional perception of women's roles in Ghana is a blockade to females' participation in STEM-related programmes, which consequently affects Ghana's economic emancipation. Considering this, the current study investigated issues of perception related to the choice of STEM-related programmes by female students. 


\section{Purpose of the Study}

The drive for this research was to:

1. Examine the self-perception of female learners offering STEM-related programmes.

2. Investigate the differences in self-perception of female students pursuing STEM programmes at the university level,

3. Investigate the relationship between female students' motivation to pursue science at SHS and STEM-related programmes, and their self-perception.

4. Find out the relationship between constraints female students encounter in pursuing STEM programmes and their self-perception.

\section{Research Question and Null Hypotheses}

The research question framed for this research is "how do female learners offering STEM-related programmes differ in their self-perception?" The following three null hypotheses $\left(\mathrm{H}_{\mathrm{o}}\right)$ were framed to guide the answering the research question:

1. There is no statistically significant difference between female students offering STEM-related programmes on their self-perceptions.

2. There is no statistically significant relationship between female students' motivation to pursue STEM-related programmes and their self-perceptions.

3. There is no statistically significant relationship between constraints female students experienced in pursuing STEM-related programmes and their self-perceptions.

\section{Delimitations}

Six public universities are offering STEM-related programmes in Ghana. But the study confined itself to the Kwame Nkrumah University Science and Technology because traditionally it promotes the study of a lot of STEM-related programmes compared with the other public universities. The study also restricted itself to only Medicine, Pharmacy, Computer Science/Information Technology, and Engineering programmes because the researcher wanted to look at technology programmes with a limited number of female involvements even though there are other science programmes like Physics which also have low participation of females. Only female learners in their final year offering the STEM-related programmes outlined previously were used as respondents because they have been in the university system for three years and might have the experience required to answer the questionnaire.

\section{Methods}

\section{Research Design}

The research applied the mixed method design, which involves both quantitative and qualitative procedures. Specifically, sequential explanatory design was used to gather and analyse quantitative data first before gathering and analysing qualitative data to understand the differences among females offering STEM Majors in their perception of learning science (Creswell \& Plano Clark, 2011).The quantitative aspect is descriptive cross-sectional survey design to examine female students' involvement in STEM majors at the university level. The survey design was to ascertain from the students their self-perception and the relationship between self-perception, motivation and constraints. The qualitative part looked at pertinent issues that arose from the quantitative analysis. 
Perception of learning science: the case of females offering STEM majors in Ghana

\section{K. Amponsah, \& M. S. Mohammed}

Sample and Sampling Technique

A non-probability sampling strategy adopted for the study was strictly purposive. The sample consisted of 328 final year female STEM major students. There were 135 engineering students, 75 medical students, 97 pharmacy students, and 21 computer science/information communication technology students. The sampling technique was derived from Yamane (1973) which is used to determine "sample size for research activities in educational and psychological measurement".

\section{Instrument}

A closed-ended and open-ended survey questionnaire (two sections-A and B) was created and issued to final year female STEM major students. Section A elicited the respondents' data and background information while section B consisted of statements on students' self-perception. Students were asked to respond to each item from strongly agreed (5), through to strongly disagreed (1), on a Likert scale of 5-1.

\section{Data Collection Procedure}

The researchers accessed the respondents through authorization acquired from the Heads of Department of the four STEM-related programmes. The investigators visited the research site twice. The first was to inform the learners about the impending administration of the instruments and any other relevant information regarding questionnaire administration. In the second visit, the questionnaire was administered, and the investigators waited and collected the answered questionnaire.

Data Analysis

Data on background information as well as the self-perception of students were analysed using frequencies, percentages and means. The ANOVA was used to determine the distinctions between students' self-perception mean and the nature of programmes offered. Subsequently, the researchers conducted the Post-hoc Hochberg GT2 tests to ascertain the precise programmes that had significant differences in students' self-perception. Eventually, Spearman rank-order correlation was analysed to explore the connection between female learners' self-perception to offer STEM related courses and their motivation as well as constraints.

\section{Results and Discussion}

\section{Self-perceptions of female students offering STEM-related programmes}

The research question looked at how female students in various STEM-related programmes differ in their self-perceptions. These perceptions were examined using a questionnaire on people's perceptions. Eight statements were used to address the research question. Table 1 shows the responses of students on their perceived people's perception about them. From Table 1, majority of learners $(77.5 \%)$ with mean 3.9 strongly agreed $(23.8 \%)$ or agreed $(53.7 \%)$ that some people believe they are very ambitious. The table, however, shows a relatively low percentage of students $(14.3 \%)$ indicating that they strongly disagree $(2.4 \%)$ or disagree $(11.9 \%)$ to that statement. Ambitious women tend to perform better in STEM subjects at high school despite the sex stereotyping and the negative perception the public has about them.

This is consistent with Baryeh, Obu and Lamptey (1999) as cited in Amponsah, Mensah, and Mensah, (2014) and Ogunjuyigbe, Ojofeitimi, and Akinlo (2006) who indicated that traditional perception "of women's roles as being essentially domestic and hence requiring little or no education is a barrier to girl's involvement in STEM education" but the ambitious ones derive inner motivation to overcome the barrier (Amponsah, Mensah, \& Mensah, 2014).

\section{Table 1: Percentage distribution and mean ratings of female students' self- perceptions}


African Journal of Educational Studies in Mathematics and Sciences Vol. 15, No. 2., 2019

\begin{tabular}{|c|c|c|c|c|c|c|c|c|}
\hline $\begin{array}{l}\text { Item } \\
\text { No. }\end{array}$ & Statements & SA & $\mathrm{A}$ & $\mathrm{U}$ & $\mathrm{D}$ & SD & Mean & $\begin{array}{l}\text { Std. } \\
\text { Dev }\end{array}$ \\
\hline 1 & $\begin{array}{l}\text { Some people believe you are an } \\
\text { exceptionally brilliant student. }\end{array}$ & 37.8 & 46.0 & 7.9 & 6.4 & 1.8 & 4.1 & 0.9 \\
\hline 2 & $\begin{array}{l}\text { Some people believe that you are very } \\
\text { ambitious. }\end{array}$ & 23.8 & 53.7 & 8.2 & 11.9 & 2.4 & 3.9 & 1.0 \\
\hline 3 & $\begin{array}{l}\text { Males prefer not to socialize with you } \\
\text { because they perceive you as being a } \\
\text { bookworm. }\end{array}$ & 8.2 & 18.3 & 7.6 & 38.7 & 27.1 & 3.6 & 1.3 \\
\hline 4 & $\begin{array}{l}\text { Females must make a lot of sacrifices } \\
\text { to be able to pursue STU programmes. }\end{array}$ & 27.4 & 32.9 & 9.8 & 20.1 & 9.8 & 3.5 & 1.3 \\
\hline 5 & $\begin{array}{l}\text { Some people believe that you do not } \\
\text { have time for fun or games. }\end{array}$ & 13.1 & 51.8 & 5.2 & 15.2 & 14.6 & 3.3 & 1.3 \\
\hline 6 & $\begin{array}{l}\text { STU programmes are very challenging } \\
\text { for females. }\end{array}$ & 16.5 & 37.8 & 8.5 & 23.5 & 13.7 & 3.2 & 1.3 \\
\hline 7 & $\begin{array}{l}\text { Some people believe that you do not } \\
\text { socialize with people. }\end{array}$ & 8.5 & 48.2 & 5.2 & 21.3 & 16.8 & 3.1 & 1.3 \\
\hline 8 & $\begin{array}{l}\text { Having a life partner will be easy } \\
\text { because of the prestige associated with } \\
\text { STU programmes. }\end{array}$ & 6.4 & 16.8 & 19.2 & 38.1 & 19.5 & 2.5 & 1.2 \\
\hline
\end{tabular}

Respondents were further asked about their opinion on the statement 'males prefer not to socialize with females in STEM majors because they perceive them to be bookworm'. Most learners $(65.8 \%)$ with a mean of 3.6 strongly disagree $(27.1 \%)$ or disagree $(38.7 \%)$ to that statement whilst $(26.5 \%)$ strongly agreed $(8.2 \%)$ or disagreed $(18.3 \%)$. It is also evident from the results that females must make a lot of sacrifices to be able to pursue science and technology-based programmes. Again, Table 1 shows that most learners (60.3\%) with mean (3.5) indicated that they strongly agree $(27.4 \%)$ or agree (32.9 that 'they must make lots of sacrifices to be able to pursue STEM related programmes. However, $(29.9 \%)$ of students indicated that they strongly disagree $(9.8 \%)$ or disagree $(20.1 \%)$. This is additionally not surprising because respondents have indicated that STEM related programmes are very difficult to study to the extent that one must go the extra mile to be able to make it. From the foregoing, it is evident that some perceptions about females in STEM related programmes seem to be true as espoused by the students analysed in this investigation. The perception is that the time needed to study courses in humanities and social sciences is less than that needed for STEM related courses. Thus, the fact that they must make lots of sacrifices to pursue science and technology-based courses cannot be overemphasized.

The mean of students' responses on peoples' perception about the students on the belief that 'they do not socialize with people' (3.1), STEM related courses are very challenging for females (3.2) and that 'they do not have time for fun or games' (3.3) is very limited. The responses of students on these perceptions as shown in Table 1, seem to suggest that students are neutral on these statements, indicating that the perception held could be true or not. The table however, shows a very low mean of 2.5 with $59 \%$ of the respondents indicating that they strongly disagree $(19.5 \%)$ or disagree $(38.1 \%)$ to the statement that having a life partner will be easy for the females just because of the position they will attain (Arnot et al.; Arnot and Phipps; FAWE, as cited in Ogunjuyigbe, Ojofeitimi \& Akinlo, 2006).

This finding is consistent with a study that ascertained that women in STEM majors might seek helpful partners in relation to their education and career aspirations as exhibited by their 


\section{K. Amponsah, \& M. S. Mohammed}

companions' support and hopes for companionship and career roles (Barth, Dunlap \& Chappetta, 2016). Successful women in STEM majors further indicated that their preferred partners are those who are helpful in their career routes, suggesting that their career choice might not necessarily influence their choice of a life partner.

Table 2 reports on perceptions of female students in various STEM-related programmes held about how people perceive them. Mean of students' responses for statements on perception were found for the four STEM related programmes respectively. The results presented in Table 2 were to find out differences in responses of students of the various programmes compared with the overall response.

\section{Table 2: Mean ratings of female students' self-perception}

\begin{tabular}{|c|c|c|c|c|c|c|}
\hline $\begin{array}{l}\text { Item } \\
\text { No }\end{array}$ & Statements & 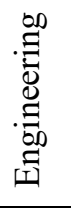 & $\begin{array}{l}. \Xi \\
: 0 \\
: 0 \\
\sum\end{array}$ & 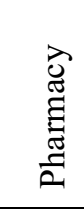 & $\begin{array}{l}\mathrm{CS} / \\
\mathrm{ICT}\end{array}$ & $\begin{array}{l}\text { ALL } \\
\text { Mean }\end{array}$ \\
\hline 1 & $\begin{array}{l}\text { Some people believe you are an exceptionally } \\
\text { brilliant student. }\end{array}$ & 4.0 & 4.3 & 4.1 & 4.1 & 4.1 \\
\hline 2 & $\begin{array}{l}\text { Some people believe that you are very } \\
\text { ambitious. }\end{array}$ & 3.9 & 3.9 & 3.8 & 3.4 & 3.9 \\
\hline 3 & $\begin{array}{l}\text { Males prefer not to socialize with you because } \\
\text { they perceive you as being a bookworm. }\end{array}$ & 3.3 & 2.7 & 3.6 & 3.5 & 3.6 \\
\hline 4 & $\begin{array}{l}\text { Females must make a lot of sacrifices to be } \\
\text { able to pursue STU programmes. }\end{array}$ & 3.7 & 3.8 & $3.1^{*}$ & $3.1^{*}$ & 3.5 \\
\hline 5 & $\begin{array}{l}\text { Some people believe that you do not have } \\
\text { time for fun or games. }\end{array}$ & 3.1 & 3.8 & 3.4 & 3.5 & 3.3 \\
\hline 6 & $\begin{array}{l}\text { STU programmes are very challenging for } \\
\text { females. }\end{array}$ & 3.1 & 3.4 & 3.1 & $3.6^{*}$ & 3.2 \\
\hline 7 & $\begin{array}{l}\text { Some people believe that you do not socialize } \\
\text { with people. }\end{array}$ & 3.1 & 3.2 & 3.1 & 3.4 & 3.1 \\
\hline 8 & $\begin{array}{l}\text { Having a life partner will be easy because of } \\
\text { the prestige associated with STU programmes. }\end{array}$ & 2.7 & 2.3 & 2.5 & 2.6 & 2.5 \\
\hline
\end{tabular}

Even though the overall mean of students' responses on the statement "science and technologybased courses are very challenging for females" was neutral, computer science /ICT students with a mean of 3.6 indicated otherwise. This suggests that computer science /ICT students are influenced by the perception that "science and technology-based courses are very challenging for females" while studying STEM programmes.

The mean of students' responses to the statement that "female students have to make lots of sacrifices to be able to pursue science and technology-based programmes" was high (3.5). However, the table shows a neutral mean for students pursuing pharmacy (3.1) and computer science/ICT (3.1). Thus, the outcomes of the investigation show that female learners are exceptionally brilliant (4.1), very ambitious (3.9), and must make lots of sacrifices (3.5), and thus makes it difficult for them to have time for fun or games (3.6). 
This study is consistent with other researches, which indicated that the perception of high school students is that STEM subjects are harder than many other subjects and that one needs more time to practice (Cuff, 2017; Xie, Fang, \& Shauman, 2015). Some studies have also revealed that a student needs to be brilliant, ambitious, focused and studious to be able to pursue STEM programmes at school (Bryan, Glynn, Kittleson, 2011; Grandy, 1998)

Comparison of Female Students Self-Perceptions

Hypothesis 1: It states that the difference between female students in the selected STEM majors on perceptions they hold about how people perceive them is not significant. The results are presented in Table 3.

Table 3: Analysis of overall mean and standard deviation of female students' self- perception

\begin{tabular}{lccc}
\hline Program & Number $(\mathrm{N})$ & Total Mean & Total S. Dev \\
\hline Engineering & 135 & 25.90 & 4.51 \\
Medicine & 75 & 27.45 & 4.30 \\
Pharmacy & 97 & 25.68 & 5.20 \\
Computer Science/ICT & 21 & 23.24 & 4.16 \\
\hline Total & 328 & 26.02 & 4.75 \\
\hline
\end{tabular}

The overall mean on perception female students held about how people perceive them for all of students' responses in each of the four programmes was calculated. Table 3 shows that female students pursuing Medicine $(\mathrm{M}=27.5, \mathrm{SD}=4.30)$ had greater overall mean than female students pursuing engineering $(\mathrm{M}=25.9, \quad \mathrm{SD}=4.51)$, pharmacy $(\mathrm{M}=25.7, \mathrm{SD}=5.20)$ and computer science/ICT $(\mathrm{M}=23.2, \mathrm{SD}=4.75)$ respectively.

Accordingly, ANOVA was conducted to ascertain whether the observed differences between female students on perceptions they held about how people perceive them were significant. Consequently, the findings are presented in Table 4.

Table 4: ANOVA on self-perceptions of female students in STEM majors

\begin{tabular}{llllll}
\hline & Sum of Squares & df & Mean Square & F & Sig. \\
\hline Between Groups & 329.613 & 3 & 109.871 & 5.061 & .002 \\
Within Groups & 7033.237 & 324 & 21.708 & & \\
total & 7362.851 & 327 & & & \\
\hline
\end{tabular}

Note: $n=135$ (Engineering); $n=75$ (Medicine); $n=97$ (Pharmacy); $n=21$ (Computer science/ICT); Significant $* p<0.05$ (2-tailed).

From Table 4, the observed difference was significant at the $\mathrm{p}<.05$ level on the perception students held about how people perceive them for the four STEM-related programmes $[\underline{F}(3,324=5.06, \underline{p}$ $<.002]$. This implies that students of the four programmes have differences in their perception. Based on the ANOVA results the hypothesis could not be supported and was therefore rejected. Subsequently, the Post-hoc analysis was conducted to appraise pair-wise differences between female students in the four STEM-related programmes in the perception they held about how people perceive them. The results are presented in Table 5.

The results indicate that perception female students held about how people perceive medical students $(\mathrm{M}=27.5, \mathrm{SD}=4.30)$ was significantly different from Computer Science/ICT students $(\mathrm{M}=23.2, \mathrm{SD}=4.16)$. This suggests that female students' perception of how people perceive 


\section{K. Amponsah, \& M. S. Mohammed}

medical students pursuing their program is different from those of computer science/ICT students. However, there was no significant difference between Engineering students $(M=25.9, S D=4.51)$ in the perception they held about how people perceive them from Pharmacy students $(\mathrm{M}=25.7$, $\mathrm{SD}=5.20)$, Medical students $(\mathrm{M}=27.5, \mathrm{SD}=4.30)$ or Computer science/ICT students $(\mathrm{M}=23.2$, $\mathrm{SD}=4.16)$.

Table 5: $\quad$ Post-hoc Hochberg GT2 analysis on female students' self-perceptions

\begin{tabular}{llccc}
\hline Program & Programme & Mean Difference & Std. Error & Sig. \\
\hline \multirow{2}{*}{ Engineering } & Medicine & -1.55 & 0.67 & 0.122 \\
& Pharmacy & 0.22 & 0.62 & 0.999 \\
& Computer Science/ICT & 2.67 & 1.09 & 0.088 \\
Medicine & Pharmacy & 1.77 & 0.72 & 0.080 \\
& Computer Science/ICT & $4.22^{*}$ & 1.15 & $0.002^{*}$ \\
Pharmacy & Computer Science/ICT & 2.44 & 1.12 & 0.167 \\
\hline
\end{tabular}

* Significant at ${ }^{*} p<0.05$ (2 tailed)

Since Engineering students are not significantly different from the others, it suggests that perception they held about how people perceive them is similar for pharmacy, medical and CS/ICT students. Similarly, comparisons between the Pharmacy students $(\mathrm{M}=25.7, \mathrm{SD}=5.20)$ and the other three groups on the perception they held about how people perceive them were not significant at $p<.05$.

\section{Relationship Between Students' Motivation and Self-Perception}

Hypothesis 2: It states that relationship between female students' motivation to pursue STU programmes and perceptions they hold about how people perceive them is not significant. This hypothesis was tested using Spearman rank-order correlation. The results are presented in Table 6.

In interpreting the results, the researcher was guided by the interpretation given by Cohen (1988), that " $\mathrm{r}_{\mathrm{s}}=.10$ to .29 or -.10 to -.29 as small; $\mathrm{r}=.30$ to .49 or -.30 to -.49 as medium; and $\mathrm{r}=.50$ to 1.0 or -.50 to -1.0 as large. The correlation coefficient may range from -1 to 1 , where -1 or 1 indicates a 'perfect' relationship. The farther the coefficient is from 0 , irrespective of whether it is positive or negative, the stronger the relationship between the two variables" (Taylor, 1997, p. 271). As shown in Table 6, no correlation existed between perceptions female students perceive people have about them and their motivation to offer STEM related courses. The correlation between perception and motivation was extremely weak $\left(\mathrm{r}_{\mathrm{s}}=0.076, \mathrm{n}=328\right.$, $\mathrm{p}$-value $\left.=0.168\right)$. The relationship was also not statistically significant. This noncorrelation suggests that people's perception of an individual does not necessarily affect one's motivation to pursue an agenda (a programme). Thus, people's perception of the students pursuing ST-based programmes does not influence their motivation to pursue those programmes. From the foregoing, we fail to reject the null hypothesis which states that there is no significant relationship between perceptions female students perceive people have about them and their motivation to pursue science and technologybased courses. 
Table 6: Spearman rank-order correlation between female students' motivation and self-perception

\begin{tabular}{llcc}
\hline & & & \\
& & & \\
Mean_Motivation Constraint & Mean_Perception \\
& Correlation Coefficient & $.219\left(^{* *}\right)$ & .076 \\
& Sig. (2-tailed) & .001 & .168 \\
& $\mathrm{~N}$ & 328 & 328 \\
Mean_Constraint & Correlation Coefficient & 1.000 & $.164(* *)$ \\
& Sig. (2-tailed) &. & .003 \\
& $\mathrm{~N}$ & 328 & 328 \\
\hline
\end{tabular}

** Spearman's rho Correlation is significant at $P<0.01$ (2-tailed).

However, Critcher and Gilovich (2010) found that "having the mind wander to positive events, to concurrent as opposed to past activities, and many events rather than just one tend to be attributed to boredom and therefore leads to perceived dissatisfaction with an ongoing task." Thus, a dissatisfied student can be demotivated, and this can affect the student's self-perception. Nevertheless, finding obtained by Critcher and Gilovich might be inconsistent with this current study, but it is believed that more research in this area cannot be overemphasized.

\section{Relationship Between Students' Constraints and Self-Perception}

Hypothesis 3: It states that the relationship between constraints female students experience in pursuing STEM related programmes and perceptions they hold about how people perceive them is not significant. This hypothesis was tested using Spearman rank-order correlation. The results of Spearman rank-order correlation between female students' constraints and peoples' perception about them are presented in Table 6 . By examining Table 6 , it was observed that the correlation between constraints female students have in pursuing STEM related programmes and the perception people have about them was a positive $\left(\mathrm{r}_{\mathrm{s}}=0.164, \mathrm{n}=328\right.$, $\mathrm{p}$-value $\left.=0.003\right)$. This suggests that the higher the constraint the greater the perception they hold people perceive about them. In other words, people's perception of students seems to influence the constraints they have. The relationship was also statistically significant with the p-value of 0.003 (sig. two-tailed) less than the alpha value of 0.01 .

Therefore, the null hypothesis of non-significant relationship between constraints female in STEM related programmes and the perception they hold people perceive about them was rejected. Hence any significant difference between constraints female students must pursue STEM related programmes and people's perception about them was not due to chance. This is not surprising because Ogunjuyigbe et al., (2006) alluded that a negative perception of teachers toward females is demotivating, depressing and unfortunate and goes a long way to affect their performance and participation in STEM subjects. Similarly, self-perception can affect people negatively or positively depending on the stimulus incorporated by the individual and can constrain their participation (Critcher \& Gilovich, 2010). Also, female students might develop negative selfperception concerning STEM careers as a result of the stereotypic role expectations different cultures have imposed on them, which can also constrain their involvement (Robak, Ward \& Ostolaza, 2005). 
Perception of learning science: the case of females offering STEM majors in Ghana

D. K. Amponsah, \& M. S. Mohammed

\section{Interviews conducted on female STEM students' self-perception}

The interview was conducted on eight female STEM students, two from each of the four STEM related programmes used for this study. They were asked about their views on the perception that female students could get pregnant or when married arrogate everything to the husband's family, therefore, they should not pursue STEM careers. The interviews were analysed by transcription and coding into themes. The results showed that traditional perception of the roles of women as being fundamentally domestic and hence needs some basic or no education does not hold any longer for the STEM students used in this study. They also agreed to the perception that female students might be impregnated even though they are still schooling, and therefore investing in their education is somewhat a waste of resources. But they reiterated that although some female learners could get pregnant while still schooling, the government of Ghana in conjunction with the Ghana Education Service (GES) and the Ministry of Education (MoE) have put in place a policy that allows the pregnant female students to go back to school after delivery. They, however, indicated that the stigma associated with it could deter some of the females from going back to school, although they are given the choice to go to other high schools.

\section{Conclusion}

Female students pursuing STEM programmes at the university level attained their self-perception as a result of their cultural influences on gender roles and expectations as well as gender stereotypes. Because of this, their choice of STEM majors becomes constrained thereby accounting for women's disproportionately low representation in STEM fields. Self-perception can influence people negatively or positively depending on the stimulus incorporated by the individual. Thus, people close to female students like their parents, teachers or even the individuals within their immediate environs can influence their self-perception, which might affect their career path.

Consequently, the study revealed that female students in STEM Majors were generally very ambitious and exceptionally brilliant but did not have enough time for fun or games because they had to make a lot of sacrifices to offer STEM related programmes. These were the dominant factors that they thought people perceived about them. Similarly, the difference between perceptions people have about STEM major students in medicine and computer science/ICT was significant. However, the difference between people's perceptions about STEM students offering pharmacy and the other programmes was not significant.

Additionally, the study showed that there was no correlation between perceptions female students perceive people have about them and their motivation to offer STEM related programmes. However, it was observed that the correlation between constraints female students have and their motivation to offer STEM related programmes was positive. Likewise, the correlation between constraints female students have and the perception people have about them even though it was comparatively low, was also positive.

The interview conducted indicated that pregnancy is no longer a barrier to educate the girl child as the government of Ghana has put in place a programme to get them back to school after delivery. They, however, indicated that the only challenge is the stigma associated with it and could deter some of the females from going back to school. Even then they indicated that the female student can enroll in a new school altogether. 
African Journal of Educational Studies in Mathematics and Sciences Vol. 15, No. 2., 2019

\section{References}

AAUW. (2010). Why so few? Women in science, technology, engineering, and mathematics. Washington, DC: Author. Retrieved March 4, 2019, from https://www.aauw.org/research/solving-the- equation/

AAUW. (2012). Graduating to a pay gap: The earnings of women and men one year after college graduation. Washington, DC: Author. Retrieved March 4, 2019, from https://www.aauw.org/research/solving-the- equation/

AAUW. (2014). The simple truth about the gender pay gap. Washington, DC: Author. Retrieved March 4, 2019, from https://www.aauw.org/research/solving-the-equation/

AAUW. (2015). Solving the equation: The variables for women's success in engineering and computing. Washington, DC: Author. Retrieved March 4, 2019, from https://www.aauw.org/research/solving-the-equation/

Amponsah, K. D., and Mensah, F. (2014). Differences among female students in science and technology-based university programmes in their motivation to learning Science in Ghana. British Journal of Education, Society \& Behavioural Science, 4(1), 120-138.

Amponsah, K. D., Mensah, F. and Mensah, A. (2014). Constraints experienced by female students pursuing science and technology-based university programmes in their learning of science in Ghana. International Journal of Research Studies in Education. 3(4), 1-12.

Appianing, J., \& Van Eck, R. N. (2015). Gender differences in college students' perceptions of technology-related jobs in computer science. International Journal of Gender, Science and Technology, 7(1), 28-56.

Barth, J. M., Dunlap, S., \& Chappetta, K. (2016). The influence of romantic partners on women in STEM majors. Sex Roles, 75, 110-125. DOI 10.1007/s11199-016-0596-z.

Bryan, R. R., Glynn, S. M., \& Kittleson, J. M. (2011). Motivation, achievement, and advanced placement intent of high school students learning science. Science Education, 95(6), 1049 -1065 .

Cohen, J. (1988). Statistical power analysis for the behavioural sciences (2nd ed.). Hillsdale, NJ Lawrence Erlbaum Associates, Publishers.

Creswell, J. W., \& Plano Clark, V. L. (2011). Designing and conducting mixed methods research (2nd ed.). Los Angeles: Sage.

Critcher, C. R., \& Gilovich, T. (2010). Inferring attitudes from mind wandering. Personality and Social Psychology Bulletin, 36(9), 1255-1266.

Cuff, B. M. P. (2017). Perceptions of subject difficulty and subject choices: Are the two linked, and if so, how? Ofqual (Strategy, Risk and Research directorate). London. Retrieved March 4, 2019, from http://ir.ua.edu/handle/123456789/5174

David L, (2017). Self-perception theory (Bem), in learning theories. Retrieved on November 4, 2019 from https://www.learning-theories.com/self-perception-theory-bem.html.

DuBow, W. (2013). By the numbers. Boulder: NCWIT. Retrieved May 4, 2019, from http://www.ncwit.org/resources/numbers

Else-Quest, N. M., Mineo, C. C., \& Higgins A. (2013). Math and science attitudes and achievement at the intersection of gender and ethnicity. Psychology of Women Quarterly, 37, 293-309. 
Perception of learning science: the case of females offering STEM majors in Ghana

\section{K. Amponsah, \& M. S. Mohammed}

Ghana Ministry of Education, MOE (1994). Policy document on technical and vocational education and training. A proposed Document, Accra: Sedco Publishing Co.

Goldstein, N. J., \& Cialdini, R. B. (2007). The spyglass self: A model of vicarious self-perception. Journal of Personality and Social Psychology, 92(3), 402-417.

Grandy, J. (1998). Persistence in the science of high-ability minority students: Results of a longitudinal study. Journal of Higher Education, 69, 589-620.

Gupta, U. G., \& Houtz, L. E. (2000). High school students' perceptions of information technology skills and careers. Journal of Industrial Technology, 16(4), 43-54.

Labour Department (2017). Labor Force Statistics from the Current Population Survey," U.S. Bureau of Labor Statistics. Retrieved May 4, 2019, from https://tinyurl.com/ybcqflfb.

Langdon, D., McKittrick, G., Khan, B., \& Doms, M. (2011). STEM: Good jobs now and for the future U.S. Department of Commerce, Economics and Statistics Administration. Retrieved May 4, 2019, from http://www.esa.doc.gov/sites/default/files/reports/documents/stemfinaly july14_1.pdf

Noonan, R. (2017). Women in STEM: 2017 update (ESA Issue Brief \#06-17). Washington, DC: Economics and Statistics Administration, U.S. Department of Commerce. Retrieved May 10, 2019, from https://tinyurl.com/yd52nlns

Ogunjuyigbe, P. O., Ojofeitimi, E. O., \& Akinlo, A. (2006). Science education in Nigeria: An examination of people's perceptions about female participation in science, mathematics, and technology. Journal of Science Education and Technology, 15(3), 277-284.

Robak, R. W., Ward, A., \& Ostolaza, K. (2005). Development of a General Measure of Individuals' Recognition of Their Self-Perception Processes. Psychology, 7, 337-344.

Sainz, M. (2011). Factors that influence girls 'orientations to ICT subjects inschools. Evidence from Spain. International Journal of Gender, Science and Technology, 3, 387-406.

Taylor, J. R. (1997). An introduction to error analysis: The study of uncertainties in physical measurements (PDF) (2nd ed.). Sausalito, CA: University Science Books. p. 217. ISBN 0-935702-75-X.

Women in STEM (2019). Percentages of women in STEM statistics. Retrieved on $10^{\text {th }}$ October 2019 from https://www.stemwomen.co.uk/blog/2019/09/women-in-stem-percentages-ofwomen-in-stem-statistics

Yamane, T. (1973). Statistics: An introductory analysis ( $3^{\text {rd }}$ ed.). New York: Harper and Row.

Xie, Y., Fang, M., \& Shauman, K. (2015). STEM Education. Annual Review of Sociology, 41(1), 331-357.

This study was conducted in collaboration between both authors. Author KDA designed the study, performed the statistical analysis, wrote the protocol and wrote the conclusion. Author SMM analysed the data, made literature searches, and wrote the first draft of the manuscript. Both authors read and approved the final manuscript. 